DOI: $10.19195 / 2084-5065.43 .5$

\title{
Wpływ osobowości sprawcy na ocenę podstaw i zakresu odpowiedzialności karnej
}

\author{
Magdalena Budyn-KuliK \\ Katedra Prawa Karnego i Kryminologii \\ Uniwersytet Marii Curie-Skłodowskiej w Lublinie
}

Inspiracją do zajęcia się tą problematyką był tekst Szanownego Pana Profesora poświęcony znaczeniu osobowości sprawcy dla oceny stopnia społecznego niebezpieczeństwa jego czynu. Profesor Kaczmarek przyjął w nim trafnie, że mimo iż czyn stanowi jedynie wyizolowany wycinek zachowania człowieka, to jeżeli jego popełnienie nie było uwarunkowane wyłącznie sytuacyjnie, lecz przede wszystkim, lub wyłącznie, osobowościowo - cechy osobowości sprawcy przejawiają się w nim¹.

Kodeks karny z 1997 r. zastąpił określenie ,społecznego niebezpieczeństwa czynu” - „społeczną szkodliwością czynu”. Nie ulega wątpliwości, że wskazana cecha w jednym i drugim przypadku odnosi się do czynu, nie do sprawcy. Nie straciło jednak aktualności stwierdzenie Jubilata, że czyn jako jakiś byt abstrakcyjny nie istnieje, popełnia go wszak człowiek ${ }^{2}$. Z drugiej strony wydaje się, że ów czynnik ludzki odgrywał wyraźniejszą rolę w przypadku społecznego niebezpieczeństwa czynu niż w przypadku społecznej szkodliwości. Jak podkreślano w literaturze prawa karnego tuż po wejściu w życie kodeksu karnego z 1997 r. — „społeczne niebezpieczeństwo" ma nieco inny charakter niż społeczna szkodliwość. „Niebezpieczeństwo” to pojęcie szersze, obejmujące nie tylko faktycznie powstałe negatywne konsekwencje czynu, lecz także te nieskonkretyzowane, o charakterze potencjalnym. „Szkodliwość” odnosi się do konkretnego czynu i jego konkretnych (wskazanych w art. 115 § 2 k.k.) konsekwencji. Dlatego na gruncie kodeksu karnego z 1969 r. można było przyjąć, że niebezpieczeństwo czynu nie sprowadzało się

1 T. Kaczmarek, Znaczenie osobowości sprawcy dla oceny stopnia społecznego niebezpieczeństwa czynu, [w:] idem, Rozważania o przestępstwie i karze. Wybór prac z okresu 40-lecia naukowej twórczości, Warszawa 2006, s. 173-176.

2 Ibidem, s. 171. 
li tylko do samego czynu. Należy również pamiętać, że kodeks karny z 1969 r. nie zawierał wskazówek, co należy brać pod uwagę przy określaniu stopnia społecznego niebezpieczeństwa czynu. Sąd miał tu zatem większą swobodę interpretacyjną.

Aktualny kodeks karny w art. 115 § 2 k.k. wymienia okoliczności, które mają być uwzględniane przy określaniu stopnia społecznej szkodliwości. Nie ma wśród nich osobowości ani okoliczności zawierającej w sobie to pojęcie właściwości osobistych. W doktrynie istnieją kontrowersje odnośnie do charakteru katalogu okoliczności wymienionych $\mathrm{w}$ tym przepisie. Formułowana jest koncepcja przedmiotowa, przedmiotowo-podmiotowa oraz kompleksowa ${ }^{3}$. Przedmiotowa uzależnia ocenę od okoliczności obiektywnych, przedmiotowych, zewnętrznych dla spraw$\mathrm{cy}^{4}$; teoria kompleksowa nakazuje przy ocenie stopnia społecznej szkodliwości brać pod uwagę wszystkie okoliczności wpływające na wymiar kary, także te niewymienione expressis verbis przez ustawodawcę, np. uprzednią karalność sprawcy, właściwości i warunki osobiste ${ }^{5}$. Za trafny należy uznać pogląd, że art. 115 $\S 2$ k.k. oparty jest na teorii przedmiotowo-podmiotowej ${ }^{6}$. Wydawałoby się więc, że na płaszczyźnie normatywnej osobowość sprawcy nie wpływa na stopień społecznej szkodliwości, jednak pośrednio czynnik ten mógłby przejawiać się w motywacji sprawcy. Wymienienie tej okoliczności wśród przesłanek wpływających na ocenę stopnia społecznej szkodliwości, zastanawia. Niezależnie od motywacji sprawcy pozbawienie życia człowieka czy zabranie należącej do niego rzeczy albo pobicie go pozostaje takim samym jakościowo czynem (oczywiście z wyłączeniem sytuacji kontratypowych). Można mówić w takiej sytuacji o większej lub mniejszej naganności czynu sprawcy (co może wpływać na stopień winy), lecz wydaje się, że motywacja sprawcy w ogóle nie powinna wpływać na stopień społecznej szkodliwości. Ustawodawca wymienił ją jednak wyraźnie w art. 115 § 2 k.k., nie można jej więc pominąć przy ustalaniu stopnia społecznej szkodliwości. Wydaje się, że w tym przypadku pod pojęciem motywacji należy rozumieć decydujący

3 A. Wąsek [w:] O. Górniok et al., Kodeks karny. Komentarz, Gdańsk 2005, t. 1, s. 803-804; J. Giezek [w:] Kodeks karny. Część ogólna. Komentarz, red. J. Giezek, Warszawa 2012, s. 676; J. Majewski [w:] Kodeks karny. Komentarz, t. I, red. A. Zoll, Warszawa 2012, s. 1346-1348.

4 J. Giezek, op. cit., s. 676.

5 Por. M. Budyn-Kulik [w:] Kodeks karny. Komentarz, red. M. Mozgawa, Warszawa 2015, s. 283. Przeciwko jej przyjęciu opowiedzieli się m.in. M. Dąbrowska-Kardas, P. Kardas, Przegląd orzecznictwa z zakresu części ogólnej prawa karnego materialnego (za rok 1995), PS 1996, nr 11-12, s. 126; J. Majewski, op. cit., s. 1347; E. Plebanek, Materialne określenie przestępstwa, Warszawa 2009, s. 270 n.; J. Warylewski, Społeczna szkodliwość czynu w nowym k.k.—próba określenia, PS 1998, nr 7-8, s. 13 n., za: A. Wąsek, op. cit., s. 804.

${ }^{6}$ M. Budyn-Kulik, M. Kulik, Społeczna szkodliwość czynu jako klauzula generalna w prawie karnym, „Annales UMCS” (w druku); M. Budyn-Kulik [w:] Kodeks karny..., s. 283; A. Zoll, Ogólne zasady odpowiedzialności karnej w projekcie k.k., PiP 1990, z. 10, s. 32. J. Giezek wyróżnia tu okoliczności o charakterze czysto przedmiotowym, czysto podmiotowym oraz mieszanym. Do tych ostatnich zalicza okoliczności popełnienia czynu oraz stopień naruszenia reguł ostrożności. Por. J. Giezek, op. cit., s. 676-677. 
o ostatecznym podjęciu decyzji popełnienia czynu zabronionego, motyw. W takim układzie związek między osobowością sprawcy a owym motywem oczywiście istnieje, ponieważ motyw został „sformułowany” w ramach specyficznych cech (warunków) konkretnego człowieka. Jeżeli zatem analiza motywacji (motywu) sprawcy prowadzi do wniosku, że jego postawy oceniane ze społecznego punktu widzenia są niewłaściwe, niepożądane i mogą generować potępiane społecznie zachowania, należy uznać, iż motywacja sprawcy wpływa wówczas na surowszą ocenę zachowania sprawcy. Powstaje jednak pytanie, czy na pewno konkretny czyn jest wówczas bardziej społecznie szkodliwy, czy pozbawienie człowieka życia $z$ miłości ${ }^{7}$ jest mniej, czy bardziej społecznie szkodliwe od pozbawienia życia z chęci zysku (np. uśmiercenie przyszłego spadkodawcy). Na pewno w tej drugiej motywacji przejawia się pewna postawa sprawcy (przedmiotowe traktowanie ludzi jako środka do celu, brak umiejętności odraczania nagród itp.). Taki sprawca jest człowiekiem — nazwijmy to — potencjalnie społecznie szkodliwym, co sprawia, że ocena moralna i prawna (na płaszczyźnie wymiaru kary) jest relatywnie surowa, a także prognoza kryminologiczna wobec takiego sprawcy jest raczej negatywna. Natomiast stopień społecznej szkodliwości czynu wydaje się pozostawać bez zmian; jej stopień jest taki sam jak w przypadku takiego samego czynu popełnionego z innej motywacji. Ponieważ jednak ustawodawca wymusza uwzględnienie motywacji przy ocenie stopnia społecznej szkodliwości, trzeba nieco sztucznie przyjąć ${ }^{8}$, iż w zależności od jej moralnej oceny stopień społecznej szkodliwości będzie wyższy, gdy jest ona naganna lub niższy, gdy zasługuje na zrozumienie. W obecnym stanie prawnym wydaje się, że nie ma możliwości ani potrzeby uwzględniania szerokiego kontekstu motywacji, czyli osobowości sprawcy, przy ocenie stopnia społecznej szkodliwości czynu. Zachowuje tu aktualność stanowisko Jubilata, że w przypadku czynów, w popełnieniu których dominującą rolę odegrał czynnik zewnętrzny (sytuacyjny), cechy osobowości sprawcy nie będą miały znaczenia ${ }^{9}$. Nieco inaczej natomiast należy ocenić znaczenie osobowości dla oceny społecznej szkodliwości sprawcy w przypadku przestępstw nieumyślnych, albowiem utrwalił się, nietrafny w moim przekonaniu, pogląd, że motywacja występuje wyłącznie w odniesieniu do umyślności ${ }^{10}$. Jednak nawet przy jego ak-

${ }^{7}$ Np. sprawca w swoim przekonaniu żywi tak mocne uczucie do pokrzywdzonej, że boi się, iż ono kiedyś się skończy, i aby temu zapobiec, chce zabić ją, a potem także siebie.

8 Ocena motywacji jest pomysłem całkowicie chybionym w świetle psychologii, ustawodawca karny uzależnia jednak od tego surowość reakcji karnej. Świadczy o tym chociażby istnienie znamienia „motywacji zasługującej na szczególne potępienie”. Por. szerzej na ten temat M. Budyn-Kulik, Środek karny pozbawienia praw publicznych. Analiza dogmatyczna i praktyka orzecznicza, „Prawo w Działaniu” 2015, nr 23, s. 124-125.

9 T. Kaczmarek, op. cit., s. 175-177.

10 Tak M.J. Lubelski, Glosa do wyroku SN z dnia 9 maja 2000 r., WA 13/2000, PiP 2001, z. 8, s. 110; J. Lachowski, Pozbawienie praw publicznych w kodeksie karnym, Prok. i Pr. 2003, nr 10, s. 59-60; odmiennie J. Kulesza [w:] System Prawa Karnego, t. 6. Kary i środki karne. Poddanie 
ceptacji, osobowość człowieka mogłaby zostać uwzględniona w kontekście reguł ostrożności. Ustawodawca nie stwarza jednak wprost takiej możliwości, ponieważ mówi tylko o rodzaju i sposobie naruszenia reguł ostrożności. Można chyba uznać, że w owym sposobie przejawiają się pewne cechy osobowościowe sprawcy, np. skłonność do niedoceniania ryzyka. Nie zawsze wpłyną one na stopień społecznej szkodliwości, na pewno - na wymiar kary.

To, że osobowość sprawcy w bardzo niewielkim stopniu wpływa na społeczną szkodliwość czynu, nie oznacza, że w ogóle przestaje być interesująca z punktu widzenia prawa karnego. Chociaż aktualny polski kodeks karny, podobnie jak czynił to kodeks karny z 1969 r., na którego gruncie powstał tekst Jubilata, nie posługuje się wprost tym pojęciem, jest ono jednak wpisane w pewne określenia, których ustawodawca używa. Należą do nich przede wszystkim właściwości osobiste sprawcy oraz motywacja.

Pojęcie właściwości osobistych występuje w następujących przepisach: art. 10 $\S 2$ k.k. (wyjątkowa odpowiedzialność karna nieletniego), 10 § 4 k.k. (wyjątkowy brak odpowiedzialności sprawcy dorosłego), art. $21 \S 1$ i $~ 2$ k.k. (indywidualizacja odpowiedzialności współdziałającego), art. 58 § 2a k.k. (ograniczenie możliwości wymierzenia kary ograniczenia wolności), art. 66 § k.k. (możliwość warunkowego umorzenia postępowania), art. 69 § 2 k.k. (możliwość warunkowego zawieszenia wykonania kary), art. 77 § 1 k.k. (możliwość warunkowego przedterminowego zwolnienia) oraz art. $53 \S 2$ k.k. Przepisy te nieprzypadkowo zostały wymienione w takiej właśnie kolejności, albowiem można je podzielić na następujące grupy: określające podstawy i zakres odpowiedzialności, dotyczące wymiaru kary, dotyczące zastosowania środków probacyjnych. Przepisem o szczególnej roli i znaczeniu w tej mierze jest art. $53 \S 2$ k.k.

$\mathrm{Z}$ kolei o motywacji sprawcy mowa jest w przepisach art. $40 \S 2$ k.k., art. 53 $\S 2$ k.k., art. $115 \S 2$ k.k. oraz art. 148 § 2 pkt 3 k.k.

Pojęcie ,właściwości osobistych” nie pokrywa się z pojęciem osobowości. Rozumie się pod nim nie tylko cechy osobowości sprawcy, lecz także jego sposób funkcjonowania w kontaktach międzyludzkich, cechy intelektu ${ }^{11}$. Jest to zatem określenie szersze. Należy podkreślić, że ustawodawca wybrał dobre rozwiązanie, nie posługując się terminem „osobowość”. Jego użycie wikłałoby jeszcze mocniej prawo karne w treści psychologiczne. Ponieważ jest to pojęcie różnie definiowane w psychologii, w zależności od przyjętej teorii, powstałyby kolejne problemy interpretacyjne. Nie byłoby ono właściwe na określenie cech sprawcy nieletniego. Poza tym w takiej sytuacji wydaje się, iż mogłaby powstać wąt-

sprawcy próbie, red. M. Melezini, Warszawa 2010, s. 475. Por. szerzej M. Budyn-Kulik, Umyślność w prawie karnym i psychologii. Teoria i praktyka sądowa, Warszawa 2015, s. 292; eadem, Środek karny pozbawienia praw publicznych. Analiza dogmatyczna i praktyka orzecznicza (raport Instytutu Wymiaru Sprawiedliwości), „Prawo w Działaniu” 2015, nr 23, s. 26.

11 M. Budyn-Kulik [w:] Kodeks karny..., s. 182. 
pliwość, czy sąd bez wywołania opinii biegłych może sam dokonać subsumcji w przypadku przepisów, które zawierałyby to określenie. Opinia biegłych sporządzona w sprawie, dotycząca także osobowości sprawcy, niewątpliwie ułatwia sądowi ustalenie owych właściwości osobistych sprawcy, jednak stwierdzenie istnienia określonych właściwości sprawcy nie musi się opierać wyłącznie na takiej opinii. Sąd może ustalić je w oparciu o inne dowody zgromadzone w sprawie, a także na podstawie bezpośredniego kontaktu na sali sądowej z oskarżonym.

Niewątpliwie jednak osobowość stanowi właściwość osobistą czy — inaczej rzecz ujmując - cechy typowe dla sprawcy, tworzące osobowość człowieka, wchodzą w skład jego właściwości osobistych. $Z$ tego względu należy przyjrzeć się dokładniej temu pojęciu.

Osobowość jest pojęciem z zakresu psychologii. Istnieje wiele teorii, które w zależności od przyjętego punktu wyjścia w różny sposób je definiują — teoria freudowska i teorie neopsychoanalityczne, teoria pola, teorie czynnikowe, teoria poznawcza, uczenia się i społecznego uczenia się, humanistyczne oraz systemowe $^{12}$. Nie jest celem tego opracowania szczegółowe ich przedstawienie, zwrócę więc uwagę na te ich elementy, które wydają się pomocne w zrozumieniu zachowania sprawcy oraz wymierzeniu mu odpowiedniej kary.

Teorie psychodynamiczne (także freudowska) akcentują złożoność i dynamikę systemu, jakim jest osobowość człowieka, rolę lęku, popędów i konfliktów między nimi oraz wpływ podświadomości na zachowanie człowieka ${ }^{13}$. Z perspektywy prawa karnego teorie te podkreślają swego rodzaju nieprzewidywalność człowieka. Tym, co sprawia, że osobowość stanowi pewną niewiadomą i trudno przewidzieć, jaka siła popchnie człowieka do jakiego zachowania, jest ogromna rola doświadczeń z dzieciństwa i relacje z rodzicami ${ }^{14}$. Z punktu widzenia prawa karnego kwestie te często pozostają poza zakresem zainteresowania sądu. Elementem składowym opinii biegłych jest wywiad od badanego. Jednak w teoriach dynamicznych bardziej interesujące jest to, czego sam człowiek nie jest świadomy, co ukrywa podświadomość. Do tych treści nie jest łatwo dotrzeć - terapia psychoanalityczna jest zwykle długa i żmudna, wymaga dużego zaangażowania i badanego, i badającego. $\mathrm{W}$ procesie karnym nie ma miejsca na tego typu działania. $\mathrm{Z}$ punktu widzenia prawa karnego teorie dynamiczne nie są więc zbyt pomocne w ustalaniu właściwości osobistych (osobowości sprawcy). Współczesna psychologia jest eklektyczna, można zatem posiłkowo czerpać z różnych teorii wtedy, gdy może się to okazać korzystne w wyjaśnianiu zachowania człowieka. W tym

12 J. Stanik, Psychologia sądowa, Warszawa 2013, s. 147 n.

13 J. Reykowski, Osobowość, [w:] Psychologia, red. T. Tomaszewski, Warszawa 1977, s. 762 771.

14 T. Jaśkiewicz-Obydzińska [w:] J.K. Gierowski, T. Jaśkiewicz-Obydzińska, M. Naja, Psychologia w postępowaniu karnym, Warszawa 2008, s. 137-146; P.K. Oleś, K. Drat-Ruszczak, Osobowość, [w:] Psychologia akademicka, t. 1, red. J. Strelau, D. Doliński, Gdańsk 2015, s. 655-683. 
przypadku pewne założenia teorii dynamicznych mogą się okazać pomocne przy odtwarzaniu motywacji sprawcy; przez ustalenie, że część tego procesu pozostała przez niego nieuświadomiona. Takie ustalenie może wpłynąć na ocenę motywacji, która może zostać uznana za okolicznością łagodzącą lub obciążającą.

Teoria humanistyczna ma charakter funkcjonalny, nie tworzy się tu abstrakcyjnej koncepcji osobowości. Zadaniem psychologa jest jej opis, służący wyjaśnieniu zachowania człowieka i zrozumieniu jego problemów. Na gruncie tej teorii akcentuje się potencjał rozwojowy jednostki. Głównym celem człowieka jest dążenie do samorealizacji, będące stałym, trwającym przez całe życie procesem. Człowiek postrzegany jest jako całość. W ujęciu tej teorii człowiek jest istotą całkowicie sprawczą. Sam wyznacza cele, do których dąży, i określa sposoby ich realizacji ${ }^{15}$. Ponieważ teoria ta ma charakter funkcjonalny, może być użyteczna dla prawa karnego, pozwalając na opis zachowania człowieka. Jednak już w wyjaśnianiu przyczyn tego zachowania potrzebny jest znaczący udział poddawanego badaniu, który przede wszystkim sam musi mieć potrzebę zrozumienia własnego postępowania oraz pewną umiejętność wglądu. Metody badawcze, charakterystyczne dla psychologii humanistycznej (np. testy projekcyjne), opierają się właśnie na takich założeniach.

Teorie cech (R.B. Catell, H. Eysenck) ujmują osobowość jako zbiór cech zewnętrznych (obserwowalnych) oraz źródłowych. Odnoszą się one do charakterystycznych sposobów zachowania, odczuwania, reagowania jednostki. Poszczególni autorzy podają odmienne zestawy cech kluczowych, np. model pięcioczynnikowy (PMO), w którym za cechy składowe osobowości uznano neurotyczność, otwartość na doświadczenia, ugodowość, ekstrawersję i sumienność. Te teorie pozwalają stosunkowo łatwo opisać osobowość sprawcy, przeanalizować i wyjaśnić jego zachowanie oraz przewidzieć możliwe postępowanie w przyszłości ${ }^{16}$. Nie bez znaczenia jest także to, że charakterystyka osobowości sprawcy, sporządzona na gruncie tej teorii, jest stosunkowo klarowna i łatwa w odbiorze przez laika (np. organ wymiaru sprawiedliwości).

Wśród teorii uczenia się warto zwrócić uwagę na teorię społecznego uczenia się (społeczno-poznawczą) A. Badury. Ma ona mniejsze znaczenie przy ocenie konkretnego zachowania sprawcy. W pewnym sensie zwalnia ona sprawcę z odpowiedzialności za kształtowanie osobowości, ponieważ podkreśla się w niej rolę bodźców i wzmocnień społecznych. Uczenie się wzorców zachowań następuje przez działanie w postaci naśladowania innych (tzw. modelowanie społeczne). Kluczem do zmiany zachowania jest przekonanie o własnej efektywności ${ }^{17}$.

15 P.K. Oleś, K. Drat-Ruszczak, op. cit., s. 683-691.

16 T. Jaśkiewicz-Obydzińska, op. cit., s. 107-113; P.K. Oleś, K. Drat-Ruszczak, op. cit., s. $802-816$.

17 P.K. Oleś, K. Drat-Ruszczak, op. cit., s. 712-719; T. Jaśkiewicz-Obydzińska, op. cit., s. 130-137; J. Stanik, op. cit., s. 163-169. 
Człowiek zostaje zatem niejako ukształtowany przez środowisko, na które ma niewielki wpływ. Teoria ta może być pomocna w wyjaśnieniu niektórych modeli zachowań pojawiających się u sprawcy, np. powielanie schematu zachowań rodzica (częste w przypadku zarówno pokrzywdzonego, jak i sprawcy przemocy w rodzinie). Oczywiście nie można wyciągać tu zbyt daleko idących wniosków odnośnie do braku możliwości samodzielnego kształtowania osobowości przez człowieka. Teoria ta natomiast pokazuje, dlaczego m.in. tak ważne jest wydawanie wyroków zawierających zrozumiałe dla obywateli rozstrzygnięcia, postrzeganych jako sprawiedliwe i słuszne.

Osobowość można również opisać jako wewnętrzny system regulacji, który pozwala na adaptację i wewnętrzną integrację myśli, uczuć, zachowania w danym środowisku w określonym wymiarze czasowym. Stanowi charakterystyczny, względnie stały sposób reagowania jednostki na środowisko społeczno-przyrodnicze oraz sposób wchodzenia przez nią w interakcje ze środowiskiem ${ }^{18}$. Na gruncie tego ujęcia stwierdzenie pewnego braku równowagi, zaburzeń osobowości każe zastanowić się nad jakością funkcjonowania człowieka. Ponieważ człowiek stanowi zrównoważony układ, zakłócenie pewnych jego elementów sprawia, że ów układ przestaje dobrze działać jako system. Stałość układu pozwala na prognozowanie zachowania sprawcy w przyszłości.

W ostatnich latach prawo karne szczególnie chętnie wykorzystuje psychologię poznawczą. Poznawcza koncepcja osobowości podejmuje próbę wyjaśnienia stałości zachowania jednostki w różnych sytuacjach, a także względnej niezmienności jej charakteru w ciągu życia. Kluczowym pojęciem są tu reprezentacje poznawcze, oparte na wiedzy człowieka o otaczającej go rzeczywistości i jej organizacji. Wiedza na temat świata, doświadczenia i obraz samego siebie zamknięte są w schematy poznawcze (reprezentacje poznawcze), które tworzą sieć poznawczą. Człowiek sam nadaje sens doświadczeniom ${ }^{19}$. Osobowość, w myśl tej koncepcji, stanowi stałe i charakterystyczne dla człowieka sposoby rozumienia otaczającej go rzeczywistości, przypisywania wartości obiektom świata społecznego, nadawania znaczenia ludziom i zdarzeniom oraz budowanie planów działania ${ }^{20}$. Ważnym procesem jest ewaluacja zdarzeń, innych ludzi i samego siebie, dzięki któremu możliwe jest dokonywanie wyborów, ustalanie hierarchii wartości ${ }^{21}$. W ujęciu tego nurtu większe znaczenie niż cechy danej osoby ma treść i sam proces poznania. Każdy człowiek ma wyjątkowy styl atrybucyjny ${ }^{22}$. Funkcją osobowości na gruncie poznawczym jest także programowanie działań (ustalanie celów, dobór

\footnotetext{
18 P.K. Oleś, K. Drat-Ruszczak, op. cit., s. 736.

19 J. Stanik, op. cit., s. 149; T. Jaśkiewicz-Obydzińska, op. cit., s. 113-129.

20 P.K. Oleś, K. Drat-Ruszczak, op. cit., s. 700-720.

21 J. Stanik, op. cit., s. 149.

22 T. Jaśkiewicz-Obydzińska, op. cit., s. 114-118.
} 
strategii) oraz sterowanie przebiegiem działania (samoregulacja) ${ }^{23}$. Takie ujęcie osobowości pozwala na przypisanie człowiekowi odpowiedzialności za jego własne zachowanie; jest istotą sprawczą, aktywnie reagującą na informacje napływające ze środowiska zewnętrznego. Stałość osobowości pozwala na postawienie prognozy kryminologicznej.

Osobowość kształtuje się przez całe życie; w szczególności w okresie dzieciństwa i młodości. Na jej ostateczny kształt mają wpływ zarówno pewne cechy wrodzone (biofizyczne), jak i proces socjalizacji, bodźce zewnętrzne oraz aktywność własna jednostki. Zasadniczy zrąb osobowości kształtuje się około 21. roku życia i pozostaje w zasadzie niezmieniony. Dlatego w przypadku nieletniego i niektórych młodocianych pojęcia właściwości osobistych nie należy utożsamiać z osobowością, chociaż, oczywiście, w skład właściwości osobistych wchodzą także cechy, które później ostatecznie ją utworzą.

Na osobowość składa się wiele różnych czynników. Można w niej wyróżnić aspekt temperamentalny (poziom reaktywności, czyli jak bardzo człowiek jest gotowy zareagować na przychodzący bodziec) i poznawczy (tworzenie schematów poznawczych, kontrola emocji, obraz samego siebie, poczucie własnej tożsamości, poczucie własnej wartości, poczucie kontroli) ${ }^{24}$. Wszystkie te czynniki w pewien sposób decydują o tym, jak w danej sytuacji zachowa się dana jednostka. Nie oznacza to jednak ścisłej determinacji. Pewne właściwości tworzą jedynie grunt pod określone sposoby reakcji, np. osoba wysokoreaktywna reaguje silnie już przy zadziałaniu słabego bodźca, nie oznacza to jednak, że konsekwencją zwrócenia jej uwagi w kinie podczas trwania seansu, aby nie rozmawiała przez telefon, jest doprowadzenie do pozbawienia życia interweniującego. Prawdopodobnie reakcja takiej osoby może być niewspółmiernie gwałtowna w stosunku do sytuacji (np. obrzucenie zwracającego uwagę licznymi wulgarnymi wyzwiskami), jednak nie doprowadzi do zamachu na życie. Owe reakcje charakterystyczne dla danego człowieka tworzą się m.in. pod wpływem procesu socjalizacji. Jednostka uczy się, spotykając się z aprobatą lub potępieniem, jakie zachowania (reakcje) są właściwe w danej sytuacji, a od jakich należy się powstrzymywać. Pewne rodzaje i sposoby reagowania na bodźce zewnętrzne dany człowiek generuje łatwiej, szybciej i bardziej ,,automatycznie" niż inne.

Nieco mylące w tym kontekście może być pojęcie tzw. automatyzmów psychologicznych. Odnosi się ono do procesów psychicznych wpływających na zachowanie człowieka, które przebiegają poza świadomością w strukturach kognitywnych przetwarzania informacji ${ }^{25}$. Owe automatyzmy są obecne w różnych sferach funkcjonowania człowieka - myślenia, odczuwania, emocji czy zachowania. Zaistnienie określonej sytuacji, pojawienie się określonych okoliczności

23 J. Stanik, op. cit., s. 149-150.

24 J. Reykowski, op. cit., s. 762-771; P.K. Oleś, K. Drat-Ruszczak, op. cit., s. 749-753.

25 J. Stanik, op. cit., s. 156-157. 
czy osób powoduje uruchomienie się automatycznych procesów psychicznych, co z kolei sprawia, że wyłączona zostaje potrzeba sterowania nimi przez świadomość. Okoliczności zewnętrzne są interpretowane przez jednostkę już na poziomie przedświadomym, innymi słowy ona sama konstruuje tzw. sytuację psychologiczną. Jest to kombinacja poznawczych, motywacyjnych i afektywnych reakcji człowieka na zdarzenia zachodzące poza nią. Na jej podstawie może dojść do reakcji świadomych ${ }^{26}$. Chociaż zatem pojawienie się pewnego czynnika sytuacyjnego uruchamia schemat i dalsze zachowanie przebiega nieświadomie, według ,wgranych procedur", nie oznacza to, że człowiek staje się jakimś bezwolnym automatem, niemającym żadnego wpływu na to, jakie decyzje podejmuje.

Cechy człowieka nie są absolutnie niezmiennie. Mogą się zmieniać np. pod wpływem doświadczeń życiowych, lecz zazwyczaj są to raczej nieznaczne modyfikacje. Drastyczne, gwałtowne zmiany osobowości mogą się pojawiać pod wpływem traumatycznych przeżyć, zmian organicznych mózgu oraz w wyniku uzależnień od substancji psychoaktywnych. Ponieważ funkcją osobowości jest integracja wewnętrzna jednostki oraz regulowanie jej relacji ze światem zewnętrznym, jeśli przestaje ją ona pełnić, mamy do czynienia z zaburzeniami osobowości. Występują one, gdy elastyczny system regulacji usztywnia się, co w efekcie powoduje przyjęcie i wykorzystywanie przez człowieka stałego, niezmiennego wzorca zachowania. Jego reakcje na różne zmieniające się sytuacje pozostają jednakowe, nieadekwatne do okoliczności. Zaburzenia osobowości stanowią efekt niedopasowania potrzeb, sposobu ich zaspokajania i sposobu realizacji zadań jednostki na danym etapie życia do wymogów społecznych. Prowadzą do częściowej dezintegracji psychiki człowieka, rozchwiania emocjonalnego, gwałtownych zmian osobowości ${ }^{27}$. Zaburzenia osobowości mogą dotyczyć różnych jej aspektów poziomu reaktywności (pobudzenia), struktur poznawczych, struktury ,ja" itp. ${ }^{28}$ W zależności od stopnia zaburzeń, zaburzenia osobowości mogą stanowić problem psychologiczny lub po osiągnięciu poziomu chorobowego — psychiatryczny ${ }^{29}$.

Osobowość sprawcy nie jest z reguły przedmiotem samoistnego badania biegłych. Jeżeli w sprawie zostają powołani biegli do zbadania stanu psychicznego sprawcy, odnoszą się oni oczywiście także do osobowości sprawcy. Jednak biegli powoływani są w przypadkach, gdy zachodzi podejrzenie umyślnego pozbawienia życia człowieka, poważnego czynu przeciwko wolności seksualnej (gwałtu) lub gdy zachowanie sprawcy jest na tyle nietypowe, że wzbudza to wątpliwości co do jego poczytalności, ewentualnie organ wymiaru sprawiedliwości posiadał informacje o przebytym urazie głowy, odbytym leczeniu psychiatrycznym, neu-

26 Ibidem, s. 159-163.

27 A. Jakubik, Zaburzenia osobowości, Warszawa 1999, s. 105 n.

28 Ibidem, s. 130-139; J. Strelau, Temperament, [w:] Psychologia ogólna, t. 4, red. T. Tomaszewski, Warszawa 1995, s. 64-66.

29 A. Jakubik, op. cit., s. 77-100. 
rologicznym lub odwykowym, jednak nawet gdy sąd dysponuje opinią biegłych dotyczącą osobowości, rzadko wykorzystuje informacje w niej zawarte w szerszym zakresie. Często ogranicza się do stwierdzenia, że czyn sprawcy jest obcy osobowości sprawcy lub stanowi zachowanie dlań typowe. Ustalenie, że czyn sprawcy nie jest normalnym dla niego sposobem reagowania na rzeczywistość, stanowi zazwyczaj okoliczność łagodzącą.

Dlatego stwierdzenie, że czyn stanowi zachowanie dotychczas obce sprawcy, może świadczyć albo o wyraźnym wpływie czynników zewnętrznych na powzięcie decyzji o jego popełnieniu, albo stanowić sygnał, że osobowość sprawcy została zaburzona. W tym drugim przypadku powstaje konieczność sprawdzenia, jaki jest zakres tych zakłóceń - czy doprowadziły one do zaburzenia funkcjonowania sprawcy na różnych płaszczyznach. Ustalenie przez biegłych u sprawcy tzw. zespołu psychoorganicznego ${ }^{30}$ może w konsekwencji doprowadzić do przyjęcia, iż popełnił on czyn w stanie poczytalności ograniczonej lub niepoczytalności.

Należy się zastanowić, czy faktycznie to, że zachowanie jest dla sprawcy typowe, powinno stanowić okoliczność de facto obciążającą. Zachowanie człowieka jest efektem procesu decyzyjnego, na który wpływa wiele czynników. Podejmowanie decyzji polega na wyborze jakiegoś zachowania ze zbioru dostępnych (możliwych) ${ }^{31}$. Psychologia częściej posługuje się pojęciem decyzji w wąskim znaczeniu, rozumiejąc pod nim jedynie wybór świadomy ${ }^{32}$.

W literaturze prawa karnego wyrażono pogląd, że decyzje człowieka zależą zarówno od jego osobowości, jak i czynników środowiskowych (zewnętrznych). Wpływ osobowości na decyzje nie jest stały, albowiem zależy od zmieniającej się i osobowości i środowiska ${ }^{33}$. Pogląd ten jest o tyle słuszny, że faktycznie przy podejmowaniu decyzji ważne są czynniki zewnętrzne i wewnętrzne, jednak właściwsze byłoby stwierdzenie, że osobowość człowieka przejawia się w pewien sposób w jego decyzjach, a nie - że osobowość wywiera wpływ na te decyzje, ponieważ podejmowanie ich nie odbywa się poza człowiekiem ${ }^{34}$.

Proces podejmowania decyzji jest złożony. Składa się z procesu przeddecyzyjnego i decyzyjnego sensu stricto. Wyodrębnia się w nim tzw. czynności przeddecyzyjne, które poprzedzają właściwy akt wyboru. Wśród nich najbardziej

30 Pojawiającego się typowo w zaawansowanym stadium choroby alkoholowej, lecz występującego także przy uszkodzeniach mózgu spowodowanych innymi przyczynami. Na temat podobieństwa objawów po urazach mózgu i po użyciu alkoholu por. szerzej M. Pąchalska, Neuropsychologia kliniczna. Urazy mózgu, t. 2, Warszawa 2007, s. 126-127, s. 169 n.

31 J. Kozielecki, Podejmowanie decyzji, [w:] Psychologia, t. 1, red. T. Tomaszewski, Warszawa 1995, s. 155.

32 M. Budyn-Kulik, Umyślność..., s. 246.

33 K. Buchała, A. Zoll, Polskie prawo karne, Warszawa 1995, s. 157.

34 M. Budyn-Kulik, Umyślność..., s. 246. 
znaczące są przewidywanie następstw decyzji (tego, co się zdarzy po jej podjęciu) oraz ocena wartości następstw decyzji ${ }^{35}$.

Przy podejmowaniu decyzji człowiek stosuje pewne procedury (o różnym stopniu złożoności i skomplikowania) ${ }^{36}$; w różny sposób dokonuje wyboru konkretnego zachowania. Wykorzystuje przy tym reguły heurystyczne ${ }^{37}$. To, jak przebiega typowo proces podejmowania decyzji u danej osoby, jakich reguł heurystycznych najczęściej ona używa, jest sprawą indywidualną, specyficzną dla jednostki.

Ważnym elementem procesu decyzyjnego jest ocena poziomu ryzyka. Poszczególni ludzie różnią się w sposobie pojmowania ryzyka ${ }^{38}$. Decydent subiektywnie ma pewien stopień pewności pojawienia się określonego następstwa czy zdarzenia. Jest to tzw. prawdopodobieństwo subiektywne. Określa ono stopień poznawczej pewności człowieka, że dane zdarzenie nastąpi w odróżnieniu od prawdopodobieństwa obiektywnego, oznaczającego rzeczywistą względną częstość zdarzeń. Prawdopodobieństwo subiektywne określa stan umysłu, obiektywne zaś — stan rzeczy ${ }^{39}$. Ma ono największy wpływ na jednostkę przy podejmowaniu decyzji. Człowiek podejmuje obiektywnie ryzykowne decyzje, gdy jest przekonany o pozytywnym efekcie podjętego zachowania.

Wydaje się, że w przypadku przepisów dotyczących podstaw odpowiedzialności karnej pod pojęciem właściwości osobistych należy rozumieć szeroko rozumiane cechy osobowości (w przypadku nieletnich — cechy, które stanowią podstawę kształtującej się osobowości). Należy tu zatem wziąć pod uwagę przede wszystkim takie czynniki, jak rodzaje schematów poznawczych (dotyczących innych i siebie), trafność przekonań o sobie oraz poziom samoregulacji, w tym także wzorce reakcji behawioralnych. W przypadku sprawców nieletnich i młodocianych (art. $10 \S 2$ i $§ 4$ k.k.) należy uwzględnić przede wszystkim poziom dojrzałości struktur poznawczych, ukształtowane postawy wobec społeczeństwa i prawa (poziom rozwoju moralnego) ${ }^{40}$. Ważnym czynnikiem jest w tym przypadku, jak się wydaje, także kwestia ulegania (bądź nie) wpływom zewnętrznym (submisywność), skłonność do uległości i podporządkowywania się, poziom lęku,

35 Ibidem, s. 159.

36 M. Budyn-Kulik, Umyślność..., s. 248.

37 J. Kozielecki, Myślenie i rozwiązywanie problemów, [w:] Psychologia, t. 1, s. 109-118; E. Aronson, T.D. Wilson, R.M. Akert, Psychologia społeczna, Poznań 2012, s. 81.

${ }^{38}$ M. Budyn-Kulik, Umyślnosśc..., s. 255-257; M. Goszczyńska, Percepcja i akceptacja ryzyka, [w:] Psychologia i poznanie, red. M. Materska, T. Tyszka, Warszawa 1992, s. 262; J. Kozielecki, Podejmowanie..., s. 171-172.

39 Por. P. Gasparski, Diagnoza - dystans - instrumentalność. Psychologiczne wyznaczniki gotowości do zapobiegania, [w:] Psychologia zachowań ryzykownych, red. M. Goszczyńska, R. Studenski, Warszawa 2006, s. 177-179; M. Goszczyńska, op. cit., s. 265-268; E. Struensee, „Objektives” Risiko und „,subjektiver” Tatbestand, JZ 1987, z. 11, s. 541-543.

40 Por. J. Stanik, op. cit., s. 61-78. 
adekwatność samooceny, potrzeba aprobaty. W przypadku dorosłych sprawców, którzy popełnili czyn we współdziałaniu przestępczym, te okoliczności również powinny mieć znaczenie.

Wbrew pozorom w art. 21 k.k. nie chodzi o osobowość sprawcy. Wynika to ze znaczenia terminu użytego w treści tego przepisu. Prima facie wydawać by się mogło, że „okoliczności osobiste” odnoszą się właśnie do osobowości sprawcy. Jest on jednak mylący, ponieważ ustawodawca posługuje się nim nieco niekonsekwentnie. Z czysto językowego punktu widzenia może byłoby lepiej, aby pojawił się tu zwrot „właściwości osobiste” lub „okoliczności o charakterze osobistym". Ten pierwszy pozwoliłby na zachowanie jednolitości terminologicznej; drugi natomiast wyraźnie wskazywałby, że chodzi o coś innego niż w określeniu „właściwości osobiste”, np. właściwości osobiste wzbogacone o motywację, czynniki emocjonalne, stosunek do pokrzywdzonego czy inne okoliczności, które są związane z osobą sprawcy, chociaż niekoniecznie mają związek z osobowością. Do tych ostatnich należy chociażby popełnienie czynu w ramach powrotności do przestępstwa. Gdyby określenie okoliczności osobistych pokrywało się z terminem „właściwości osobiste”, stwierdzenie z art. 21 k.k. wydawać by się mogło pewną oczywistością: skoro mowa o okolicznościach osobistych, to trudno jest uzależniać od nich stopień surowości reakcji karnej wobec osoby, która takich cech nie ma. Jeżeli okoliczności osobiste oznaczają to samo co właściwości osobiste, to właściwie tylko wiek może być uznany za okoliczność, która może być łatwo obiektywnie stwierdzona i zauważona przez współdziałającego przy popełnianiu czynu zabronionego. Cechy osobowości lub inne właściwości osobiste nie zawsze są współdziałającym znane lub/i prawidłowo interpretowane.

Wydaje się jednak, że określenie „okoliczności osobiste” zostało użyte w innym, szerszym znaczeniu. W polskim kodeksie karnym większość okoliczności o charakterze ściśle osobistym (osobowość lub pewne właściwości składające się na nią) ma raczej charakter łagodzący niż obciążający. Jedynie niektóre rodzaje motywacji, np. nienawiść (art. 256 k.k.), można uznać za okoliczność należącą do znamion czynu zabronionego, jednak zależy od niej byt tego czynu zabronionego, a więc odpowiedzialność karna w ogóle, a nie tylko wyższa karalność. Okolicznością o charakterze obciążającym, związaną z osobą, jest chyba tylko powrotność do przestępstwa i pośrednio - wiek (popełnienie czynu wspólnie z nieletnim).

W grupie przepisów odnoszących się do wymiaru kary konieczność uwzględnienia właściwości osobistych sprawcy (osobowości) została wprowadzona wyłącznie w odniesieniu do wymierzenia kary ograniczenia wolności i grzywny. Na marginesie należy zauważyć, że przepis art. 58 § 2a k.k. jest w tym zakresie zbędny, ponieważ ocenę zasadności wymierzenia kary określonego rodzaju, z uwzględnieniem m.in. właściwości osobistych sprawcy, przewiduje art. 53 k.k. Przy ocenie zdatności oskarżonego do wykonania ciążącego nań obowiązku nieodpłatnej, kontrolowanej pracy na cele społeczne sąd powinien wziąć pod uwagę 
przede wszystkim postawy sprawcy wobec wykonywania pracy w ogóle, obowiązkowość, zdyscyplinowanie itp. Problemem jest jednak to, że orzeczenie kary ograniczenia wolności możliwe jest w przypadku występków o mniejszym ciężarze gatunkowym. Tymczasem opinia biegłych odnośnie do stanu psychicznego sprawcy, w której zostaje również mniej lub bardziej dokładnie scharakteryzowana osobowość sprawcy, pojawia się raczej w sprawach o zbrodnie lub ciężkie występki przeciwko życiu i zdrowiu oraz przeciwko wolności seksualnej. W tym ostatnim przypadku opinia biegłych skupia się przede wszystkim na zaburzeniach seksualnych, które nie muszą być wyłącznym wyznacznikiem zachowania sprawcy.

W przypadku przepisów pozwalających na rezygnację z części represji karnej (środki probacyjne) osobowość sprawcy powinna być oceniana pod kątem możliwości zmiany schematów poznawczych związanych z postrzeganiem norm i konieczności ich przestrzegania, określania pożądanych celów i sposobów ich osiągania. Stosunkowo najpełniejszym materiałem poglądowym w tej mierze dysponuje sąd na etapie postępowania wykonawczego. Podczas odbywania kary pozbawienia wolności funkcjonariusze służby więziennej gromadzą informacje na temat osadzonego, na które składają się m.in. badania psychologiczne oraz obserwacja zachowania osadzonego. Możliwe jest zatem odtworzenie wzorów reakcji behawioralnej, a na podstawie danych o karach dyscyplinarnych i nagrodach można mieć pewne wyobrażenie na temat umiejętności uczenia się i modyfikowania zachowań pod wpływem nagród i kar. W przypadku warunkowego umorzenia postępowania i warunkowego zawieszenia wykonania kary sąd nie dysponuje zazwyczaj bogatym materiałem pozwalającym ocenić, czy właściwości osobiste sprawcy w części stanowiącej jego osobowość pozwalają na udzielenie sprawcy dobrodziejstwa zastosowania tych instytucji. Jest to możliwe w odniesieniu do lżejszych przestępstw, więc prawdopodobieństwo, że sprawca został poddany badaniu przez biegłego, jest nikłe.

Największe znaczenie ma osobowość sprawcy z perspektywy art. 53, w szczególności art. $53 \S 2$ k.k.

Przy wymiarze kary osobowość uwzględniana jest niejako podwójnie, a nawet wielokrotnie. Najwyraźniej przejawia się, oczywiście, przez motywację i właściwości osobiste sprawcy, lecz jest obecna także w takich czynnikach, jak sposób zachowania się sprawcy (typowy-nietypowy), rodzaj i stopień naruszenia obowiązków (postawa wobec obowiązków i konieczności ich wypełniania), sposób życia przed popełnieniem przestępstwa (z wykluczeniem niezależnych od sprawcy zdarzeń losowych, przejawiają się w nim postawy sprawcy np. przez skłonność do podejmowania zachowań społecznie oczekiwanych — podejmowanie wysiłków w celu uzyskania edukacji, znalezienia stałego zgodnego z prawem źródła utrzymania, tworzenie trwałej dojrzałej relacji z partnerem/ partnerką itp.); zachowanie po popełnieniu czynu (zdolność do autorefleksji, zrozumienia konsekwencji własnych zachowań). W kontekście art. $53 \S 2$ k.k. osobowość sprawcy powinna być 
uwzględniana w najszerszym możliwym znaczeniu i zakresie. Wnioski wyprowadzone w tej mierze przez sąd powinny w sposób całościowy odnosić się do właściwości sprawcy, uwzględniając fakt, iż człowiek jest jednością psychofizyczną. W związku z tym nie można nie brać pod uwagę pewnych cech przy interpretacji niektórych okoliczności, a w odniesieniu do innych — brać.

Warto zwrócić uwagę na to, że w przypadku art. $53 \S 2$ k.k. również motywacja powinna być rozumiana w szerszym tego słowa znaczeniu ${ }^{41}$. Mniejsze znaczenie ma tu wskazanie konkretnego motywu, np. finansowego, zemsty, chęci dokuczenia itp.; bardziej chodzi właśnie o uwzględnienie tego, co doprowadziło do takiego, a nie innego ukształtowania procesu decyzyjnego. Dla sądu zwykle ważniejsza jest motywacja zawężona do konkretnego motywu, zwłaszcza gdy w odniesieniu do konkretnego czynu sprawcy można potraktować go jako motywację zasługującą na szczególne potępienie. Tymczasem istotniejsze jest to, jak sprawca wyznacza cele do osiągnięcia, co sprawia, że wybiera takie, a nie inne metody ich zrealizowania, jak przebiega ustalanie tzw. antycypowanej wartości gratyfikacyjnej wyniku, jakie sprawca zna i stosuje sposoby redukcji napięcia motywacyjnego i w jaki sposób dokonuje oceny subiektywnego prawdopodobieństwa osiągnięcia wyniku ${ }^{42}$. Motywacja w szerszym znaczeniu jest względnie stałą tendencją do analizowania określonych celów, wartości czy zadań życiowych i jako taka wiąże się z osobowością człowieka ${ }^{43}$.

Wydaje się, że właściwe byłoby również uwzględnianie tej przesłanki przy ocenie poddania się przez sprawcy mediacji. Wnikliwa analiza jego osobowości może np. prowadzić do wniosku, iż podjęcie próby pojednania się z pokrzywdzonym może mieć charakter czysto instrumentalny i być spowodowane li tylko chęcią poprawienia własnej sytuacji procesowej. Inna rzecz, że z brzmienia art. $53 \S 3$ k.k. nie wynika, aby powody podjęcia tego kroku miały jakiekolwiek znaczenie dla pozytywnego uwzględnienia faktu poddania się mediacji.

Jak trafnie zauważył swego czasu Jubilat — ustalenia w kwestii osobowości sprawcy wymagają wiedzy specjalistycznej. Jest to kolejna płaszczyzna nieporozumienia między organami wymiaru sprawiedliwości a biegłymi (psychologami). Bardzo często w opiniach biegłych psychologów rozważania dotyczące osobowości sprawcy sprowadzają się do stwierdzenia nieprawidłowości w określonej sferze funkcjonowania i/lub ,zdiagnozowania” zaburzeń osobowości. To ostatnie odbywa się często w sposób lakoniczny - przez podanie nazwy zaburzenia, ewen-

${ }^{41}$ M. Budyn, Motywacja zastugująca na szczególne potępienie. Próba analizy, Prok. i Pr. 2000 , nr 9, s. 25.

42 J. Reykowski, Emocje i motywacja, [w:] Psychologia, red. T. Tomaszewski, Warszawa 1977.

43 M. Budyn, Motywacja..., s. 25-26; C.N. Cofer, M.H. Appley, Motywacja. Teoria i badanie, Warszawa 1982, s. 15; J. Reykowski, Z zagadnień psychologii motywacji, Warszawa 1982, s. 18; idem, Emocje i motywacja. Osobowość jako centralny system regulacji i integracji czynności człowieka, [w:] Psychologia, s. 579 n.; S. Mika, Psychologia społeczna, Warszawa 1981, s. 81-84; K. Obuchowski, Psychologia dążén ludzkich, Warszawa 1972, s. 39 n. 
tualnie wymienione zostają hasłowo cechy charakterystyczne tego zaburzenia, zwykle bez zrelatywizowania ich do konkretnej osoby. Tymczasem przydatniejsze z punktu widzenia potrzeb orzeczniczych sądu byłoby przedstawienie osobowości sprawcy w sposób opisowy, funkcjonalny. Biegli nie do końca zdają sobie sprawę z tego, jakie informacje potrzebne są sądowi, sąd zaś zwykle nie umie w odpowiedni sposób zapytać biegłych o to, co go interesuje.

W szczególności problematyczną kwestią jest to, jak ocenić, np. z punktu widzenia oceny naganności zachowania sprawcy, fakt, że czyn był zgodny z jego osobowością lub różnił się znacząco od typowych wzorców behawioralnych. Można by prima facie uznać, że skoro czyn stanowi zachowanie dla sprawcy typowe, wpisane niejako w jego osobowość, nie można mu z tego powodu postawić zarzutu, ponieważ jest ono wówczas efektem doświadczeń, posiadanych schematów poznawczych itp. To, że osobowość sprawcy ukształtowała się w określonym kształcie, nie jest efektem jego świadomej pracy; jej tworzenie się nie jest procesem kontrolowalnym. Można się zastanawiać, czy uzależnianie pośrednio stopnia winy i wprost wymiaru kary od osobowości (właściwości osobistych) człowieka nie jest swego rodzaju wyjściem na przedpole odpowiedzialności i czy jest to w tej postaci uprawnione. $Z$ drugiej strony jednak człowiek co prawda nie kontroluje w pełni procesu kształtowania się osobowości, nie znaczy to jednak, że nie może kontrolować swojego zachowania w konkretnych sytuacjach, modyfikując reakcje automatyczne, powstrzymując się od pewnych reakcji lub unikając znalezienia się pod wpływem bodźców mogących wyzwolić reakcje, o których wie, że są niepożądane. W takim układzie można uznać, że zachowanie zgodne z wzorcem, co do którego sprawca wie lub przy dołożeniu minimalnej staranności powinien wiedzieć, iż jest negatywnie oceniane przez środowisko społeczne, stanowi okoliczność obciążającą sprawcę. Wiedząc (lub mając powinność dowiedzenia się), że takie zachowanie jest niepożądane i spotyka się z potępieniem, powinien podjąć starania w celu jego modyfikacji i dostosowania do oczekiwań społecznych.

W przypadku gdy czyn sprawcy stanowi zachowanie całkowicie obce wzorcowi behawioralnemu sprawcy, istnieją w zasadzie dwie możliwości wyjaśnienia takiego stanu rzeczy. Pierwszy, że najprawdopodobniej znaczącą rolę w popełnieniu czynu odegrał/y czynnik/i zewnętrzny/e, nagłe, nowe, zaskakujące, w odpowiedzi na pojawienie się których sprawca nie miał gotowych reakcji. Drugim wytłumaczeniem jest pojawienie się zmian funkcjonalnych lub organicznych w mózgu, powodujących gwałtowną zmianę cech, postaw, zachowania. Jeżeli zmiany w mózgu są na tyle poważne, że ich wpływ powoduje brak rozpoznania znaczenia czynu lub/i pokierowania własnym postępowaniem, poczytalność sprawcy zostanie wyłączona albo odpowiednio ograniczona, gdy nie dojdzie do całkowitego zniesienia, lecz tylko do ograniczenia w znacznym stopniu).

Bardziej interesująca jest kwestia, jak powinien wpływać na wymiar kary fakt, że jest on osobowości sprawcy obcy lub przeciwnie — typowy dla niego; któ- 
ra z tych okoliczności powinna zostać uznana za łagodzącą, a która za obciążającą. Jeżeli czyn stanowi zwykły dla sprawcy sposób reakcji, wynika z posiadanych przez niego schematów poznawczych, prezentowanych postaw, interpretacji rzeczywistości, prima facie trudno sprawcy stawiać zarzut niewłaściwego zachowania. Należy pamiętać o tym, że żadna z teorii osobowości nie zakłada pełnego determinizmu i predestynacji. Człowiek zwykle nie zdaje sobie sprawy z tego, jakie okoliczności i w jaki sposób kształtują jego osobowość; może jednak korygować zachowania, które są społecznie nieakceptowane, modyfikując je do społecznie aprobowanych. Jeżeli tego nie robi, demonstruje określoną postawę wobec norm społecznych (i prawnych). Samo zachowanie nie staje się wtedy naganniejsze, lecz tak ukształtowana osobowość niewątpliwie ma znaczenie z punktu widzenia celów kary określonych w art. $53 \S 1$ k.k., przede wszystkim — zapobiegawczy i wychowawczy. Trudniej jest je osiągnąć. Aby mieć pewność, że zostały one zrealizowane, trzeba by oddziaływać na osobowość sprawcy i spróbować wpłynąć na jego postawy, przekonstruować schematy poznawcze itp. Wymagałoby to pracy terapeutycznej - długotrwałej, czasochłonnej i zapewne, co nie jest bez znaczenia — kosztownej. Ważniejsze jest jednak to, że byłaby to bardzo głęboka ingerencja w istotę sprawcy; jego tożsamość. Z pewnością przymusowe poddanie się takim oddziaływaniom należałoby uznać za naruszanie praw człowieka. Nawet gdyby dało się obronić tezę, że tak nie jest, nie dałoby się takich oddziaływań skutecznie przeprowadzić, jeżeli sprawca nie chciałby się zmienić. Nie wystarczyłaby tu formalnie wyrażona przez niego zgoda. Musiałby on żywić głębokie przekonanie o potrzebie zmiany i podjąć faktyczne kroki, by to osiągnąć. Cele zapobiegawczy i wychowawczy można jednak zrealizować w inny sposób, dobierając karę tak, aby jej surowość lub/i dolegliwość powstrzymała sprawcę w przyszłości od popełnienia czynu zabronionego. Nie ma wówczas znaczenia, że zachowania społecznie aprobowane pozostaną zachowaniami obcymi osobowości sprawcy; ważne jest tylko to, że przestanie on podejmować zachowania niepożądane.

Ustawodawca czyni z właściwości osobistych sprawcy okoliczność dość istotną z punktu widzenia podstaw i zakresu odpowiedzialności karnej. Jest to kolejna $\mathrm{z}$ okoliczności pozaprawnych, którą włącza on do treści przepisów. Wydaje się, że niektórych przypadkach, gdy przepis zawiera tę przesłankę, stwierdzenie okoliczności o takim charakterze nie jest niezbędne z perspektywy poniesienia przez sprawcę odpowiedzialności karnej w odpowiednim wymiarze (np. przy karze ograniczenia wolności). Samo zadekretowanie przez ustawodawcę konieczności uwzględniania pewnych okoliczności nie zawsze przekłada się na faktyczne ich badanie w praktyce stosowania prawa. Wydaje się, że lepszym rozwiązaniem byłoby ograniczenie występowania przesłanki „właściwości osobistych” w kodeksie karnym do art. $10 \S 2$ k.k. i art. 53 k.k. Niewątpliwie istotną rolę powinna ona odgrywać na etapie wykonywania kary, zarówno pozbawienia wolności (klasyfikacja osadzonych, odroczenie, udzielenie przerwy lub przepustek, warunkowe 
przedterminowe zwolnienie), jak i kar wolnościowych (modyfikacja obowiązków probacyjnych). Uwzględnienie cech osobowości sprawcy na tym etapie jest ważne z punktu widzenia możliwości zrealizowania celów kary.

\section{The wrong-doer's personality influence on the assessment of criminal liability grounds and scope}

\section{Summary}

A criminal act is done in certain circumstances, but it reflects also the wrong-doer's personality and his/her social dangerousness. The Criminal Code of 1997 replaced the term "social dangerousness" with "social harmfulness". Art. 115 \& 2 CC points out the circumstances that should be considered while assessing the level of social harmfulness; with no personality-like circumstance mentioned there. Such factor is indirectly hidden in the phenomena of motivation. While one considers acts that are done mostly because of some external (situation-related) factors, the wrong-doer's personality does not matter. One's personality should be considered as far as involuntary acts are concerned. The wrong-doer's personality is interesting for criminal law purposes, because of some terms the Polish CC uses, like personal characteristics (Art. $10 \S 2,10$ $\S 4$, Art. $21 \S 1$ i 2 , Art. $58 \S 2$ a, Art. $66 \S 1$, Art. $69 \S 2$, Art. $77 \S 1$, Art. 53 2) and motivation (Art. $40 \S 2$, Art. $53 \S 2$, Art. $115 \S 2$, Art. $148 \S 2$ point 3). The term "personal characteristics" is wider than "personality". There are many psychological theories that try to explain what personality is (Freud's, factors, cognitive, social learning, humanistic and systematic theory). Personality is a fairly well-fixed regulation system that starts to function about the age of 21 . It consists of many elements. Personality can change drastically during lifetime under certain traumatic circumstances, organic brain changes or addictions to psychoactive substances. The act of a wrongdoer may express his/her typical characteristics (personality) but it may not be so typical for him/ her, either. Usually, when it is typical the court treats it as an aggravating circumstance and when untypical - as a mitigating one. Personality issues need some specialist knowledge. Personal characteristics are important as far as criminal liability is concerned. Otherwise, their presence should be limited in the Criminal Code and used only in Art. $10 \S 2$ and Art. 53. They should be considered as far as the period of punishment execution and probation measures are concerned.

Keywords: personality, social harmfulness, personal characteristics, criminal liability, sentencing. 